\title{
Molecules important for thyroid hormone synthesis and action - known facts and future perspectives
}

\author{
Klaudia Brix ${ }^{1 \dagger}$, Dagmar Führer ${ }^{2 \dagger}$, Heike Biebermann ${ }^{3 *+}$
}

\begin{abstract}
Thyroid hormones are of crucial importance for the functioning of nearly every organ. Remarkably, disturbances of thyroid hormone synthesis and function are among the most common endocrine disorders affecting approximately one third of the working German population. Over the last ten years our understanding of biosynthesis and functioning of these hormones has increased tremendously. This includes the identification of proteins involved in thyroid hormone biosynthesis like Thox2 and Dehal where mutations in these genes are responsible for certain degrees of hypothyroidism. One of the most important findings was the identification of a specific transporter for triiodothyronine (T3), the monocarboxylate transporter 8 (MCT8) responsible for directed transport of T3 into target cells and for export of thyroid hormones out of thyroid epithelial cells. Genetic disturbances of MCT8 in patients result in a biochemical constellation of high T3 levels in combination with low or normal TSH and thyroxine levels leading to a new syndrome of severe X-linked mental retardation. Importantly mice lacking MCT8 presented only with a mild phenotype, indicating that compensatory mechanisms exist in mice. Moreover, it has become clear that not only genomic actions of T3 exist. T3 is also capable to activate adhesion receptors and it signals via activation of PI3K and MAPK pathways. Most recently, thyroid hormone derivatives were identified, the thyronamines which are decarboxylated thyroid hormones initiating physiological actions like lowering body temperature and heart rate, thereby acting in opposite direction to the classical thyroid hormones. So far it is believed that thyronamines function via the activation of a G-protein coupled receptor, TAAR1. The objective of this review is to summarise the recent findings in thyroid hormone synthesis and action and to discuss their implications for diagnosis of thyroid disease and for treatment of patients.
\end{abstract}

\section{Introduction}

\section{Health consequences of disturbed thyroid hormone action}

Thyroid hormones are of significant importance for regular functioning of almost all body organs. Thyroxine (T4) is the main hormone released from the thyroid gland and it is transformed into biologically active 3',3,5-triiodothyronine (T3) via 5'-deiodinases of thyroid hormone target cells [1]. For thyroid hormone synthesis, sufficient supply of the thyroid gland with essential micronutrients such as iodine and selenium is crucial.

\footnotetext{
* Correspondence: heike.biebermann@charite.de

† Contributed equally

${ }^{3}$ Institute of Experimental Pediatric Endocrinology, Charité

Universitätsmedizin Berlin, Augustenburger Platz 1, 13353 Berlin, Germany

Full list of author information is available at the end of the article
}

The most important target tissues of thyroid hormones are the central nervous system, the cardiovascular system and the skeleton. Moreover, due to the increasing incidence of obesity worldwide, thyroid hormone action in adipose tissue has re-gained increasing interest for understanding energy homeostasis [2].

Disturbance of thyroid hormone synthesis and thyroid hormone actions, further referred to as thyroid disorders, are among the most common endocrine afflictions and they require special attention in specific life phases. For instance, undiagnosed hypothyroidism during pregnancy will lead to irreparable central nervous system (CNS) defects in the newborn because the development of the child in utero is critically affected by the mother's thyroid status [3]. Therefore and to avoid fatal consequences of a lack of thyroid hormone synthesis after birth, eventually leading to severe mental retardation, 
thyroid stimulating hormone (TSH)-screening of newborns [4] was implemented in Germany and in other countries. In action since the late 1970s and with a clear improvement in those areas of the world where TSHscreening was first introduced, a marked decrease in cretinism was observed.

Thyroid hormone (TH) action serves important regulatory functions throughout all phases of life. Disturbed $\mathrm{TH}$ action is linked with major health problems especially in critical life phases such as development, disease or ageing. Thus, lack of $\mathrm{TH}$ action in the adult brain causes impaired neuro-cognitive function and psychiatric states such as severe depression and dementia [5]. Not only hypothyroidism but also hyperthyroidism affects the CNS and frequently results in agitation, increased irritability and dysregulation of body temperature. There is ample epidemiological evidence that both, hyper- and hypothyroidism confer an increased risk for cardiovascular morbidity (e.g. arrhythmia, heart failure and stroke) and mortality. Moreover, thyroid disorders affect maturation and turnover rates of bone. For example, children with hyperthyroidism show advanced bone age, and post-menopausal women with thyrotoxicosis are at risk for osteoporosis. Furthermore, adiposity is associated with altered levels of measurable thyroid function parameters, whereby it is not known however whether the obesity state influences the set-point for thyroid function parameters or vice versa. Besides the common health issues, life threatening conditions may either arise from severely disturbed thyroid hormone action or are accompanied by altered thyroid hormone action. These include e.g. thyroid storm with a mortality of more than $30 \%$, which at present can only be diagnosed on clinical grounds since measurement of thyroid hormone levels is not useful and may be identical to those in patients with uncomplicated thyrotoxicosis or the non-thyroid illness syndrome in intensive care patients with e.g. sepsis.

Health-economical dimensions of thyroid disorders are shown most plainly by the example of latent hypothyroidism which is evident in about $20 \%$ of all individuals at the age of 60-79 years, with higher incidences in women than in men [6]. On top of this, an increase in the number of patients with thyroid disorders is expected in the future. Possible causes are anthropogenic in origin and are represented by a variety of environmental substances, so-called endocrine disruptors such as estrogen-derivates and PBCBs, that affect the endocrine system at large including the thyroid gland and thyroid hormone actions [7].

Furthermore, classical epidemiology on large cohorts (SHIP and KORA) has underlined that manifest and even more so, subclinical thyroid disorders are often associated with other, quite frequently occurring pathophysiological processes $[8,9]$. These include, but are not limited to left-ventricular hypertrophy, atherosclerosis with increased risk for stroke and coronary heart disease, disorders in lipid metabolism, osteoporosis and neurodegenerative diseases. However, subclinical hyperthyroidism was found not to be associated with e. g. changes in blood pressure in the SHIP cohort study [9] although serum TSH levels in the upper reference range were indicative of endothelial dysfunction [10], highlighting the necessity of further investigations aiming at a better definition of the healthy thyroid state.

\section{New aspects of thyroid hormone synthesis}

A number of molecular causes of thyroid dysgenesis, accounting for approx. $80 \%$ of cases suffering from congenital hypothyroidism $(\mathrm{CH})$, have been identified over the last few years and were shown to include mutations in transcription factors important for thyroid development such as Pax8, Nkx2.1, FoxE1, and HoxA3[11]. Mutations in these genes often also lead to developmental dysfunction in organs other than the thyroid, thereby affecting the lung and the central nervous system (Nkx2.1) [12], or the kidney (PAX8) [13]. However, only about $5 \%$ of these genetic defects could account for the pathogenesis of thyroid dysgenesis [14]. Therefore, nonclassical mechanisms involving epigenetic regulation are to be considered in future as modulators of gene expression during development of the thyroid.

In addition, genetic defects have been detected in all those genes bearing an essential role in the biosynthesis of thyroid hormones (approx. 10 to $15 \%$ of $\mathrm{CH}$ cases). These include the gene for the prohormone thyroglobulin (Tg) itself [15]; the thyroid stimulating hormone receptor $(T S H R)[16]$, and the thyroid peroxidase (TPO) [17]; as well as genes relevant for iodide transport, i.e. the sodium-iodide symporter (NIS) [18] at the basolateral and Pendrin[19] at the apical pole of thyroid epithelial cells. Furthermore, the gene products of Dehal[20] and Thox2[21] as well as inactivating and activating mutations of the Gs alpha gene [22] have been added to the growing list of candidate proteins with important thyroid-specific functions. Recently, potassium channel subunits Kcnq1 and Kcne2 were found to be crucial for TSH-stimulated thyroid hormone biosynthesis. Mice lacking Kcne 2 suffer from impaired iodide uptake into the thyroid gland and exhibit signs of hypothyroidism [23].

A more profound understanding of thyroid hormone biosynthesis has also led to a clearer view on the molecular regulation of the thyroid gland and has increased our knowledge about the differentiated state of thyroid epithelial cells. In this context, novel players have been identified, which are important for the maintenance of thyroid physiology, i.e. molybdenum-dependent enzymes 
with important functions in the oxidative system of thyrocytes [24] and molecules that play a role in thyroglobulin processing for thyroid hormone liberation and release from the thyroid gland (megalin and cysteine cathepsins) [25-27].

Many of these players have been known for long, but it was only recently that the impact of mutations in thyroid-specific genes for thyroid physiology was set into context for a clearer depiction of the interactions and cross-relations between the many molecules and pathways relevant for thyroid biology. The regulation governing the functions of thyroid-specific proteins and their precise roles in the etiology of thyroid disorders will enable us to understand their mechanisms of action in detail and will advance our knowledge on the molecular biology of the thyroid gland.

\section{Novel concepts of transmembrane and intracellular thyroid hormone actions}

Previous textbook knowledge of thyroid hormone entry into cells included a diffusion-based passive transmembrane passage for thyroid hormones which are lipophilic but charged molecules. However, an eye-opening revelation was the identification of the MCT8 transporter (SLC16A2) that selectively enables T3 transport into target cells [28]. This important finding explained at the molecular level the phenotype of severe X-linked mental retardation and disrupted locomotor development of patients with the Allan Herndon Dudley (AHD) syndrome, already described in the 1940s. These patients carry a defect in the MCT8 transporter, which explains why T3 does not reach all of its target cells in sufficient quantities during development. At the same time AHD patients show highly elevated serum T3 levels with unaltered to elevated TSH contradicting the "normal feedback scenario". Thus it needs to be investigated further whether the abnormally high T3 levels in conditions of MCT8 defects that are linked with normal to slightly elevated TSH levels may cause thyrotoxic effects in TH target tissues other than the central nervous system [29]. However this clinical observation prompted thyroidologists to question the classical views on thyroid regulation. Subsequently, other TH transporter candidates have been identified (e.g. Oatp14, Lat1, Lat2, Mct10) in mice and require functional characterization [30-33]. It will be important in future to not only identify the tissue distribution patterns of $\mathrm{TH}$ transporters but more so, to clarify their potential contributions to the intracellular compartmentalisation of $\mathrm{TH}$ so that a clearer picture is gained on the sub-cellular gradients of $\mathrm{TH}$ and how specific compartments within cells, besides the nucleus, are supplied with $\mathrm{TH}$ in order to contribute or to withstand non-classical $\mathrm{TH}$ actions. Further $\mathrm{TH}$ transporters are eagerly awaited to be defined (Figure 1).
Another unexpected finding of recent research projects was the identification of thyroid hormone derivatives, the so-called thyronamines [34]. These are decarboxylated thyroid hormones that exert effects with kinetics different from those of thyroid hormone mediated actions and principally counter-acting them (so called "cool thyroid hormones"). Most obvious effects of thyronamines are observed in decreased heart rates and in negative regulation of body temperature. Thyronamines display their effects via activating a new subfamily of G-protein-coupled receptors (GPCRs), the trace amine associated receptors (TAARs) [35-37]. Because of their central roles in signalling resulting in a multitude of regulatory effects on almost all biological processes, GPCRs are interesting targets for pharmacological intervention [38]. Hence, the development of new therapeutic agents for regulation of heart beat frequency and of body temperature is now discussed in light of emergency treatments of stroke or acute myocardial infarction. Moreover, thyronamine-based therapies are expected to enter intensive care medical treatments.

Furthermore several lines of evidence suggest that in addition to the classic nuclear thyroid hormone action, rapid plasma membrane-initiated effects of thyroid hormones exist. Signalling via adhesion receptors $(\alpha v \beta 3$ integrins) and activation of intracellular PI-3 kinase and mitogen activated protein (MAP) kinase pathways have been proposed to account for these effects [39-41]. The precise mechanisms and the physiological implications of non-classical $\mathrm{TH}$ actions however remain elusive.

Besides the classic hormones $\mathrm{T} 4$ and $\mathrm{T} 3$ new data demonstrate that the rare thyroid hormone metabolite 3,5-T2 is effective in the prevention of high fat dietinduced adiposity and prevents hepatic steatosis, however, without exerting the severe side effects on the cardiac system that have been observed with T3-based treatments [42] . The vital importance of thyroid hormones for regulation of thermogenesis and for maintenance of the homeostasis of the mitochondrial energy metabolism has long been established. However, the functional interactions between the activities of uncoupling proteins (UCP) which are triggered by T3 and catecholamines affecting brown adipose tissue (BAT) as well as skeletal muscle of the adult, provide new possibilities for therapeutic intervention in obesity that have only recently become apparent [43].

Thus in the present concept of thyroid hormone action, the cellular thyroid hormone status is defined by thyroid hormone transporters, thyroid hormone membrane receptors, thyroid hormone molecules and TAM mediated actions (Figure 1B). It is highly likely and corroborated by recent experimental results that cell typespecificity, with respect to thyroid hormone signalling, 
A

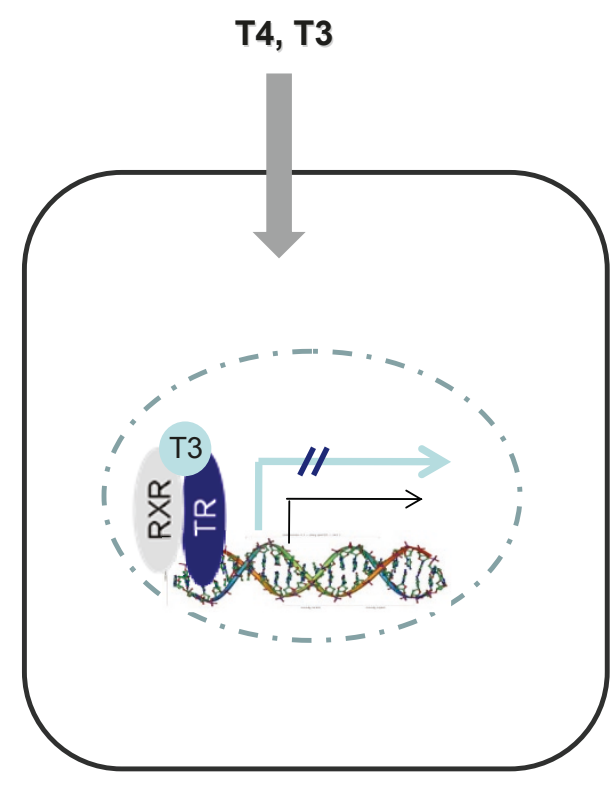

B

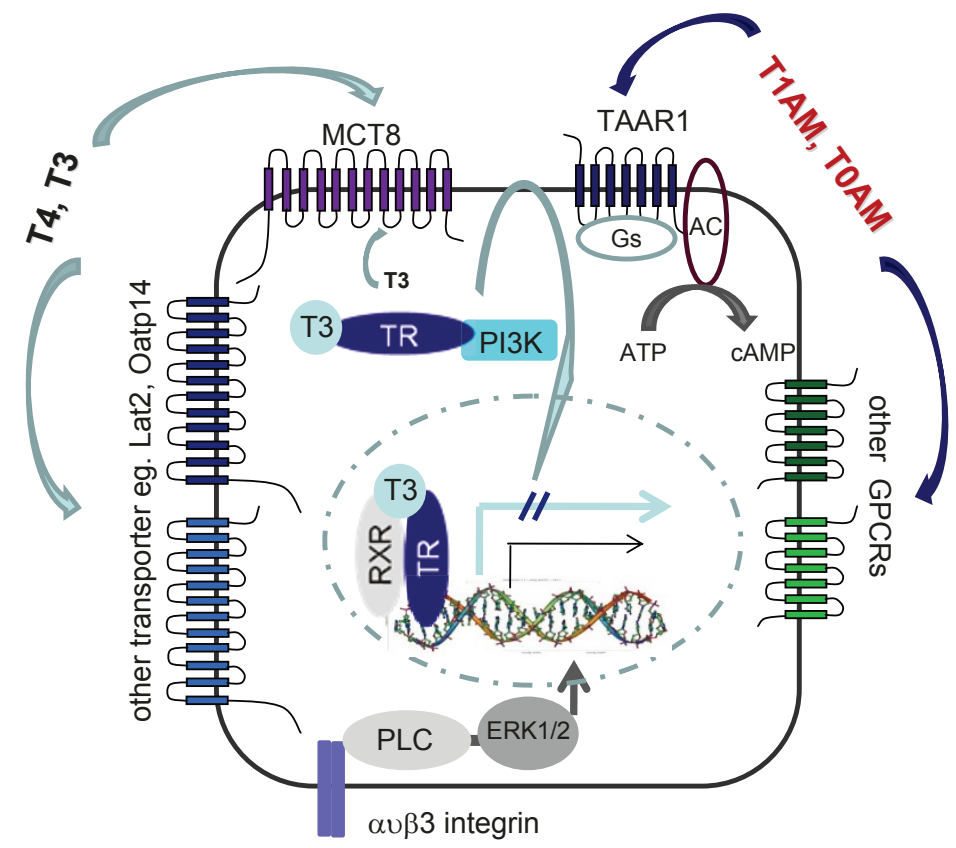

Figure 1 Old and new concepts of thyroid hormone action. A: Old concept of thyroid hormone action. In former times it was assumed that thyroid hormones are able to pass the plasma membrane by passive transport. Once in the cytosol T4 is deiodinated to T3 which exerts genomic effects by binding to the thyroid hormone receptor (TR). After hetero-dimerization with other nuclear receptors like retinoic $X$ receptor (RXR), transcriptional regulation is initiated resulting in activation or inactivation of target genes. B: New concepts of thyroid hormone action. Thyroid hormones enter a target cell via specific transporters, e.g. T3 uses the monocarboxylate transporter MCT8 while T4 entry is mediated by Lat2 or Oatp14. Moreover, T3 can interact with $\alpha / \beta 3$ integrins to induce ERK1/2 signalling. Cytosolic T3 exerts genomic effects but can additionally also act by non-genomic means after TR binding and activation of down-stream PI-3 kinase. Likewise, the naturally occurring iodothyronine $\mathrm{T} 2$ is believed to stimulate metabolic rates via mitochondrial pathways, thereby bypassing genomic regulation. Besides thyroid hormones, derivatives like the thyronamines T1AM or TOAM, modulate the action of T3, e.g. counter-acting its effects in certain target cells. Thyronamines (TAMS) bind to and activate G-protein coupled receptors (GPCRs) of the trace amine associated receptor (TAAR) family. So far, it is only known that TAAR1 is activated by TAMs and signals via adenylylcyclase (AC) activation with subsequent rise of cAMP levels. However other GPCRs are likely targets for thyroid hormone derivatives.

differs within and in between different organs. Thereby novel avenues are opened for refinement of the concept of organ physiology and the role of thyroid hormone derived signals including their cellular compartmentalization. Such information will complement and add to our current concepts of classical TH actions.

\section{Perspectives of better understanding of TH action} Epidemiology has shown unequivocally that with age the ratio of subclinical to clinically manifest thyroid disorders increases, thus thyroid disorders are a disease of the ageing population. In light of the demographic changes of our societies, improvements of human health care systems should not be limited to better management of only cardiovascular disorders, cancer, and neurodegenerative diseases. We believe that modern and future-oriented health politics and policy making institutions need to take an endocrine organ into account that has been known for decades, but is still not fully "revealed", the thyroid gland.

The knowledge of known thyroid-specific genes, the discovery of new genes as well as the investigations of thyroid hormone- and thyronamine-mediated actions on their many target tissues will entail therapeutic potentials not only for the prevention and treatment of thyroid disorders but importantly also for major health problems that are, as yet, not well treatable with thyroid hormone molecules.

Further investigations of a seemingly familiar but frequently overlooked endocrine organ, the thyroid gland, bear hopes and promises for better management of future challenges arising from current common environmental stressors of human health such as endocrine disruptors. 


\section{List of abbreviations used}

AC: adenylylcyclase; AHD: Allan Herndon Dudley; BAT: brown adipose tissue; CH: congenital hypothyroidism; CNS: central nervous system; GPCRs: Gprotein coupled receptors; MAP: mitogen activated protein; NIS: sodiumiodide symporter; RXR: retinoic X receptor; T3: 3',3,5-trioodothyronine; T4: thyroxine; TAAR: trace amine associated receptor; TAMs: thyronamines; Tg: thyroglobulin; TH: thyroid hormone; TPO: thyroid peroxidase; TR: thyroid hormone receptor; TSH: thyroid stimulating hormone; TSHR: thyroid stimulating hormone receptor; UCP: uncoupling proteins;

\section{Acknowledgements}

This work was supported by the Deutsche Forschungsgemeinschaft, graduate college 1208 "Hormonal Regulation of Energy Metabolism, Body Weight and Growth", TP1.

The authors are grateful to Marc Scheibner, Dr. Sofia Tedelind and Dr. Denise Yu for manuscript editing.

This article has been published as part of Thyroid Research Volume 4 Supplement 1, 2011: New aspects of thyroid hormone synthesis and action. The full contents of the supplement are available online at http://www. thyroidresearchjournal.com/supplements/4/S

\section{Author details}

'School of Engineering and Science, Jacobs University Bremen, Research II, Campus Ring 6, 28759 Bremen, Germany. ${ }^{2}$ Universitätsklinikum Leipzig Medizinische Klinik III, 04103 Leipzig, Germany; as of June 2011: Klinik für Endokrinologie, Zentrum für Innere Medizin, Bereich Forschung und Lehre im Zentrallabor, 45147 Essen, Germany. ${ }^{3}$ Institute of Experimental Pediatric Endocrinology, Charité Universitätsmedizin Berlin, Augustenburger Platz 1, 13353 Berlin, Germany.

\section{Authors' contribution}

$\mathrm{KBr}$, DF and $\mathrm{HB}$ contributed equally, read and approved the manuscript.

\section{Competing interests}

The authors declare that they have no competing interests.

Published: 3 August 2011

\section{References}

1. Kohrle J: The deiodinase family: selenoenzymes regulating thyroid hormone availability and action. Cell Mol Life Sci 2000, 57:1853-1863.

2. Obregon MJ: Thyroid hormone and adipocyte differentiation. Thyroid 2008, 18:185-195.

3. Gartner R: Thyroid diseases in pregnancy. Curr Opin Obstet Gynecol 2009, 21:501-507.

4. Gruters A, l'Allemand D, Beyer P, Eibs G, Helge H, Korth-Schutz S, Oberdisse U, Schwartz-Bickenbach D, Weber B: Screening of newborn infants for hypothyroidism in Berlin (West) 1978-1982. Monatsschr Kinderheilkd 1983, 131:100-105.

5. Bauer M, Goetz T, Glenn T, Whybrow PC: The thyroid-brain interaction in thyroid disorders and mood disorders. J Neuroendocrinol 2008, 20:1101-1114

6. Biondi B, Cooper DS: The clinical significance of subclinical thyroid dysfunction. Endocr Rev 2008, 29:76-131.

7. Boas M, Main KM, Feldt-Rasmussen U: Environmental chemicals and thyroid function: an update. Curr Opin Endocrinol Diabetes Obes 2009, 16:385-391.

8. Ittermann T, Haring R, Sauer S, Wallaschofski H, Dorr M, Nauck M, Volzke H: Decreased serum TSH levels are not associated with mortality in the adult northeast German population. Eur J Endocrinol 2010, 162:579-585.

9. Volzke H, Ittermann T, Schmidt CO, Dorr M, John U, Wallaschofski H, Stricker BH, Felix SB, Rettig R: Subclinical hyperthyroidism and blood pressure in a population-based prospective cohort study. Eur J Endocrinol 2009, 161:615-621.

10. Volzke H, Robinson DM, Spielhagen T, Nauck M, Obst A, Ewert R, Wolff B, Wallaschofski H, Felix SB, Dorr M: Are serum thyrotropin levels within the reference range associated with endothelial function? Eur Heart J 2009, 30:217-224.

11. Gruters A, Krude H, Biebermann $\mathrm{H}$ : Molecular genetic defects in congenital hypothyroidism. Eur J Endocrinol 2004, 151(Suppl 3):U39-44.
12. Krude $H$, Schutz $B$, Biebermann $H$, von Moers $A$, Schnabel D, Neitzel $H$, Tonnies H, Weise D, Lafferty A, Schwarz S, et al: Choreoathetosis, hypothyroidism, and pulmonary alterations due to human NKX2-1 haploinsufficiency. J Clin Invest 2002, 109:475-480.

13. Al Taji E, Biebermann H, Limanova Z, Hnikova O, Zikmund J, Dame C, Gruters A, Lebl J, Krude H: Screening for mutations in transcription factors in a Czech cohort of 170 patients with congenital and earlyonset hypothyroidism: identification of a novel PAX8 mutation in dominantly inherited early-onset non-autoimmune hypothyroidism. Eur J Endocrinol 2007, 156:521-529.

14. Kuehnen P, Grueters A, Krude H: Two puzzling cases of thyroid dysgenesis. Horm Res 2009, 71(Suppl 1):93-97.

15. leiri T, Cochaux P, Targovnik HM, Suzuki M, Shimoda S, Perret J, Vassart G: A $3^{\prime}$ splice site mutation in the thyroglobulin gene responsible for congenital goiter with hypothyroidism. J Clin Invest 1991, 88:1901-1905.

16. Biebermann H, Schoneberg T, Krude H, Schultz G, Gudermann T, Gruters A: Mutations of the human thyrotropin receptor gene causing thyroid hypoplasia and persistent congenital hypothyroidism. J Clin Endocrinol Metab 1997, 82:3471-3480.

17. Abramowicz MJ, Targovnik HM, Varela V, Cochaux P, Krawiec L, Pisarev MA, Propato FV, Juvenal G, Chester HA, Vassart G: Identification of a mutation in the coding sequence of the human thyroid peroxidase gene causing congenital goiter. J Clin Invest 1992, 90:1200-1204.

18. Fujiwara $\mathrm{H}$ : Congenital hypothyroidism caused by a mutation in the $\mathrm{Na}$ +/l-symporter. Nat Genet 1997, 16(2):124-125.

19. Everett LA, Glaser B, Beck JC, Idol JR, Buchs A, Heyman M, Adawi F, Hazani E, Nassir E, Baxevanis AD, et al: Pendred syndrome is caused by mutations in a putative sulphate transporter gene (PDS). Nat Genet 1997, 17:411-422.

20. Moreno JC, Klootwijk W, van Toor H, Pinto G, D'Alessandro M, Leger A, Goudie D, Polak M, Gruters A, Visser TJ: Mutations in the iodotyrosine deiodinase gene and hypothyroidism. N Engl J Med 2008, 358:1811-1818.

21. Moreno JC, Bikker H, Kempers MJ, van Trotsenburg AS, Baas F, de Vijlder JJ, Vulsma T, Ris-Stalpers C: Inactivating mutations in the gene for thyroid oxidase 2 (THOX2) and congenital hypothyroidism. N Engl J Med 2002, 347:95-102.

22. Spada A, Mantovani G, Lania A: Inactivating and activating mutations of the Gs alpha gene. Ann Endocrinol (Paris) 2005, 66:258-263.

23. Roepke TK, King EC, Reyna-Neyra A, Paroder M, Purtell K, Koba W, Fine E, Lerner DJ, Carrasco N, Abbott GW: Kcne2 deletion uncovers its crucial role in thyroid hormone biosynthesis. Nat Med 2009, 15:1186-1194.

24. Havemeyer A, Bittner F, Wollers S, Mendel R, Kunze T, Clement B: Identification of the missing component in the mitochondrial benzamidoxime prodrug-converting system as a novel molybdenum enzyme. J Biol Chem 2006, 281:34796-34802.

25. Friedrichs B, Tepel C, Reinheckel T, Deussing J, von Figura K, Herzog V, Peters C, Saftig P, Brix K: Thyroid functions of mouse cathepsins B, K, and L. J Clin Invest 2003, 111:1733-1745.

26. Jordans S, Jenko-Kokalj S, Kuhl NM, Tedelind S, Sendt W, Bromme D, Turk D, Brix $K$ : Monitoring compartment-specific substrate cleavage by cathepsins $\mathrm{B}, \mathrm{K}, \mathrm{L}$, and $\mathrm{S}$ at physiological $\mathrm{pH}$ and redox conditions. BMC Biochem 2009, 10:23.

27. Marino M, Zheng G, Chiovato L, Pinchera A, Brown D, Andrews D, McCluskey RT: Role of megalin (gp330) in transcytosis of thyroglobulin by thyroid cells. A novel function in the control of thyroid hormone release. J Biol Chem 2000, 275:7125-7137.

28. Friesema EC, Ganguly S, Abdalla A, Manning Fox JE, Halestrap AP, Visser TJ: Identification of monocarboxylate transporter 8 as a specific thyroid hormone transporter. J Biol Chem 2003, 278:40128-40135.

29. Friesema EC, Grueters A, Biebermann H, Krude H, von Moers A, Reeser M, Barrett TG, Mancilla EE, Svensson J, Kester MH, et al: Association between mutations in a thyroid hormone transporter and severe X-linked psychomotor retardation. Lancet 2004, 364:1435-1437.

30. Sugiyama D, Kusuhara H, Taniguchi H, Ishikawa S, Nozaki Y, Aburatani H, Sugiyama $Y$ : Functional characterization of rat brain-specific organic anion transporter (Oatp14) at the blood-brain barrier: high affinity transporter for thyroxine. J Biol Chem 2003, 278:43489-43495.

31. Friesema EC, Docter R, Moerings EP, Verrey F, Krenning EP, Hennemann G, Visser TJ: Thyroid hormone transport by the heterodimeric human system L amino acid transporter. Endocrinology 2001, 142:4339-4348. 
32. Ritchie JW, Taylor PM: Role of the System L permease LAT1 in amino acid and iodothyronine transport in placenta. Biochem J 2001, 356:719-725.

33. Friesema EC, Jansen J, Jachtenberg JW, Visser WE, Kester MH, Visser TJ: Effective cellular uptake and efflux of thyroid hormone by human monocarboxylate transporter 10. Mol Endocrinol 2008, 22:1357-1369.

34. Scanlan TS, Suchland KL, Hart ME, Chiellini G, Huang Y, Kruzich PJ, Frascarelli S, Crossley DA, Bunzow JR, Ronca-Testoni S, et al: 3lodothyronamine is an endogenous and rapid-acting derivative of thyroid hormone. Nat Med 2004, 10:638-642

35. Borowsky B, Adham N, Jones KA, Raddatz R, Artymyshyn R, Ogozalek KL, Durkin MM, Lakhlani PP, Bonini JA, Pathirana S, et al: Trace amines: identification of a family of mammalian $\mathrm{G}$ protein-coupled receptors. Proc Natl Acad Sci U S A 2001, 98:8966-8971.

36. Staubert C, Boselt I, Bohnekamp J, Rompler H, Enard W, Schoneberg T: Structural and functional evolution of the trace amine-associated receptors TAAR3, TAAR4 and TAAR5 in primates. PLoS One 2010, 5: e11133.

37. Piehl S, Hoefig CS, Scanlan TS, Kohrle J: Thyronamines-Past, Present, and Future. Endocr Rev 2011, 32:64-80.

38. Panetta R, Greenwood MT: Physiological relevance of GPCR oligomerization and its impact on drug discovery. Drug Discov Today 2008, 13:1059-1066.

39. Bergh JJ, Lin HY, Lansing L, Mohamed SN, Davis FB, Mousa S, Davis PJ: Integrin alphaVbeta3 contains a cell surface receptor site for thyroid hormone that is linked to activation of mitogen-activated protein kinase and induction of angiogenesis. Endocrinology 2005, 146:2864-2871.

40. Furuya F, Lu C, Guigon CJ, Cheng SY: Nongenomic activation of phosphatidylinositol 3-kinase signaling by thyroid hormone receptors. Steroids 2009, 74:628-634.

41. Scarlett A, Parsons MP, Hanson PL, Sidhu KK, Milligan TP, Burrin JM: Thyroid hormone stimulation of extracellular signal-regulated kinase and cell proliferation in human osteoblast-like cells is initiated at integrin alphaVbeta3. J Endocrinol 2008, 196:509-517.

42. Lanni A, Moreno M, Lombardi $A$, de Lange $P$, Silvestri $E$, Ragni M, Farina $P$, Baccari GC, Fallahi P, Antonelli A, Goglia F: 3,5-diiodo-L-thyronine powerfully reduces adiposity in rats by increasing the burning of fats. FASEB J 2005, 19:1552-1554

43. Ribeiro MO, Bianco SD, Kaneshige M, Schultz JJ, Cheng SY, Bianco AC, Brent GA: Expression of uncoupling protein 1 in mouse brown adipose tissue is thyroid hormone receptor-beta isoform specific and required for adaptive thermogenesis. Endocrinology 2010, 151:432-440.

doi:10.1186/1756-6614-4-S1-S9

Cite this article as: Brix et al:: Molecules important for thyroid hormone synthesis and action - known facts and future perspectives. Thyroid Research 2011 4(Suppl 1):S9.

\section{Submit your next manuscript to BioMed Central and take full advantage of:}

- Convenient online submission

- Thorough peer review

- No space constraints or color figure charges

- Immediate publication on acceptance

- Inclusion in PubMed, CAS, Scopus and Google Scholar

- Research which is freely available for redistribution 